\title{
Challenging History: Past Reconstruction in Colum McCann's Songdogs
}

\author{
By Andrzej Gabiński \\ Universidad Complutense de Madrid
}

Copyright (c) 2007 by Andrzej Gabiński. This text may be archived and redistributed both in electronic form and in hard copy, provided that the author and journal are properly cited and no fee is charged for access.

\begin{abstract}
The present paper analyses the way in which Colum McCann's novel Songdogs (1995) constitutes an attempt at reconstructing and reconciling oneself with the past, a theme that a number of contemporary critics perceive as characteristic of the Irish literary experience. It will be argued that via the novel's non-linear, fragmented narrative structure, on the one hand, and its frequent use of static images reminiscent of photography on the other, McCann engages the concept of memory and translates its founding functional principles into a personal literary technique. The task of recovering significance from distinct media - be it still images or the novel's texture - will be construed as operating on two levels. The novel's mixed plot lines constructed out of apparently unrelated clusters of images and the reader's efforts at organising them into larger meaningful compositions will be understood as parallel to the protagonist's attempts at forging all the stories embedded in Songdogs into a master narrative of his family's history.
\end{abstract}

Key Words. Memory, reconstruction, photography, gaze, contemporary Irish literature.

Resumen. El presente ensayo analiza la manera en la que la novela de Colum McCann Songdogs (1995) constituye una tentativa de reconstruir y reconciliarse con el pasado, un tema considerado por un gran número de críticos contemporáneos como característico de la experiencia literaria irlandesa. Se propondrá que la estructura no-lineal de la narrativa por un lado y su uso frecuente de imágenes estáticas reminiscentes de la fotografía por el otro le permiten a McCann adentrarse en el concepto de la memoria y traducir sus principios funcionales en una técnica literaria personal. La tarea de recuperar significados de distintos medios - sean imágenes fijas o la textura de la novela - se observará en dos niveles distintos. Los varios argumentos, construidos a partir de grupos de imágenes aparentemente independientes, y los esfuerzos por parte del lector para organizarlos en unidades significativas más grandes serán paralelos a los intentos del protagonista de aunar todas las historias incluidas en Songdogs en una narración completa de su historia familiar.

Palabras clave: Memoria, reconstrucción, fotografía, mirada, literatura irlandesa contemporánea

One of the major difficulties anyone interested in investigating contemporary Irish literature encounters is the ephemeral, undefined status of that literature; on the one hand, Ireland has undoubtedly produced fine and by now well-recognised authors whose names can be found in any literary encyclopaedia, but, on the other hand, these texts somehow fail to give account of recent Irish literature as a coherent and structured phenomenon. Looking through some of the volumes devoted to literary history, both world and European, one cannot fail to notice an absence - it appears that Irish literature is a series of particular figures, Joyce, Heaney, McCourt or O'Brien, to name just a few, who produce, or have produced, exceptional literary works that are, nevertheless, suspended in a contextual void. Rather than forming a continuum that would emphasize structural, linguistic or thematic similarities and respective influences, recent Irish literature is 
summarized by a handful of names and titles. In a lecture on contemporary Irish fiction delivered at the Irish Writers' Centre, Derek Hand asserts that: "Contemporary writers are thus disconnected from a literary tradition and have no points of reference or models that they can look to for guidance", and emphasises how numerous critics argue an almost palpable tension existent within that literature between the somehow discarded, remote and inaccessible past and the novel present obliged to affirm its novelty exactly by disconnecting itself from its possible traditions ${ }^{1}$ That tension, the critics maintain, is a pre-requisite for any contemporary writer to engage seriously in Irish literature.

Hand opposes to such a drastic rejection of Irish literary traditions and, instead, proposes a different understanding of the relation between present and past. Following Fintan O'Toole, Hand underlines the connection between the two temporal realities and the importance of their eventual reconciliation. He writes:

The best Irish writing over the last 200 years concerns itself with trying to make connections between the past and the present in order that a more fruitful future can be imagined. And indeed, the same - I would argue - is true of the best Irish fiction in the present moment.

The above observation is certainly true when considering the writing of Colum $\mathrm{McCann}^{2}$, a contemporary Irish writer, whose novel Songdogs (1995) the present paper will analyse. It will be argued that the novel's fragmented structure and its three parallel plotlines reflect the tension between past and present commented upon above; the simultaneous development of the three stories

\footnotetext{
${ }^{1}$ María Losada Friend, for instance, observes that: “... este acercamiento novedoso que quiere estudiar un presente literario e intelectual de múltiples voces, sigue poniendo de manifiesto la recurrente e irremediable aparición del pasado en obras irlandesas" (Losada 2003: 57). The critic further argues that numerous Irish authors represent the constraining past either in the form of ghosts that haunt their literary realities or, more recently, as memory, a non-physical collective body of experiences and beliefs that must be reconciled. The latter proposal appears much more revealing in the light of the arguments that will be developed in this paper.
}

will be considered as an attempt to establish a continuity between the two opposing temporal realities in order to re-construct the complete history of a mixed-blood, Mexican-Irish family.

The novel will also be argued to dramatise a re-encounter between past and present on a more personal level, between its protagonist and his elderly father, two personae that need to confront their past in order to give some significance to the vague, fluctuating and almost phantasmal present they live in. The analysis will pay particular attention to the novel's imagery, its insistence on visual elements within its textual body and the author's use of static, photographic scenes rather than swift narrative developments. In the course of the discussion the concept of the gaze as understood in psychoanalytical criticism will be employed in order to provide both a clearer understanding of the act of visual recreation of meaning and a deeper insight into the tensions present between the novel's characters. Finally, the discussion will consider the concepts of history and memory in order to argue their infinitely subjective status within the novel; both will be perceived as highly private notions whose content and signification, contrary to traditional considerations, are actively constructed on a personal level.

\section{How does a plot resemble a photo album?}

As has been pointed out above, McCann's Songdogs includes three plot lines that, although simultaneous in their development, constitute three distinct stories: the first one is that of the narrator's homecoming and his painful re-encounter with his father; it encompasses seven days and constitutes the novel's temporal super-structure. The second story resembles a fragmented biographical narrative - it reconstructs the life of the narrator's father, Michael, until the present day where it inevitably blends in with the first, surface plot line. Thirdly, the novel also discloses some of the moments from the protagonist's life prior to the homecoming (this plot-line is the most fragmented and least

\footnotetext{
${ }^{2}$ Some publishers and critics provide an alternative spelling of the author's name, MacCann. For reasons of clarity the former spelling, McCann, will be used in the present essay.
} 
complete) -incidentally the third plot-line also eventually coincides with the original plot-line, which in a sense, apart from functioning as the surface narrative that at particular moments triggers off the immersion into one of the two sub plot-lines, might be considered in terms of a caesura- its resolution also terminates the other two plot-lines.

McCann's novel is a continuous interplay of flash-forwards and flashbacks, and the intention of this paper is to focus on the writer's technique of moving from one fictitious reality into another. The element that somehow allows for the three plot-lines to remain closely inter-connected is the figure of the father or, to be more precise, the photos he took throughout life, photos that serve as both a testimony of his voyages and miseries, and a structural component that effectively binds the three narratives present within the novel. Although all the seven chapters (corresponding to the seven days the protagonist spends with his father in his hometown of Mayo, a rural community in North-West Ireland) of Songdogs begin on the level of the surface narrative, each section of the book contains numerous flashbacks into one of the remaining plot-lines and it is noteworthy to observe that these reminiscences are usually activated by images, highly visual sections and static descriptions of persons, places or sensations:

... I would go downtown to buy flagons of hard cider, then return ... to clean the names of the two Protestant ladies underneath their explosion of cerise wildflowers.

He was almost twenty-one when he stood in a Fascist camp and watched great white loaves of bread showering down on Madrid ... (McCann 1995: 17, layout original)

... he would have frozen down there otherwise, the length of time I knew it was going to take him to make that fly, with all its colours, all its trapped motion.

Bus stations are among the saddest places in America. Everyone looking for a way out. Slinking around. Looking for lost children. Keeping eyes glued on nothing in particular, waiting for life to happen. (McCann 1995: 130, layout original)

The shifts from one plot line to another are usually rapid and unannounced; one section (from any of the three narratives) finishes and immediately another section (from a different narrative) begins without any transition whatsoever. With but a few exceptions, McCann is consistent in employing static images as intersection points between the narratives throughout the novel; one reason for such a structuring might be the relatively limited action that takes place within each of the plot-lines - apart from sections from the father's pseudo-biographic narrative, which in some respects resembles a road novel ${ }^{3}$, Songdogs does not include movement, mobility or rapid changes of narrative pace. Rather, its semantic significance, which will be commented upon in the following section, favours a more slowly measured and slowly unfolding development that the technique of employing still images certainly favours.

The status of static descriptions within the novel's structure - as pivotal points that allow the narratives to overlap - is paired with their profound semantic significance that offers another possible explanation for the particular composition of Songdogs. As has been pointed out above, the protagonist's father is a photographer who has been restlessly portraying his entire life, the places he has visited, the people he has met, the human miseries and joys he has witnessed, on Polaroid paper. At one point in the novel, while recalling his own past in the mountains

\footnotetext{
${ }^{3}$ McCann's novel resembles in many respects the most important road novel in American literary tradition, Jack Kerouac's On the Road (1957). Apart from telling the story of a journey, an obvious pre-requisite of that sub-genre, the author of Songdogs establishes numerous thematic continuities with the beat writer, among them matching locations (rural, dust-covered towns in Mexico, the hippy, avant-garde atmosphere of San Francisco, the raw, mountainous regions of NorthWest United States, crowded, tumultuous New York), a parallel temporal frame (the 1960's) and ultimately the condition of travelling towards an unknown destination, emphasizing the experience of movement as such, rather than the prospect of an arrival. Other critics, such as Christina Hunt, have also noted the impact of Kerouac's writing upon McCann: "McCann's writing is influenced by Jack Kerouac, whose novels his journalist father would bring back from the States" (Hunt 1998: 261). A more thorough analysis of the similarities between the two novels would exceed the limitations of the present paper and neither is it its primary concern.
} 
of Wyoming, the narrator confesses: "I trudged home under the blanket-black night ... took out my photo album, flicked through it. It had become a habit of mine, looking at the album" (McCann 1995: 135). Although the protagonistrefers to the album as his it is evident that the photos included in it are also some of his father's snapshots taken years ago in all the places the old man had visited. If looking through the album is the protagonist's habit then it might be conjectured that while visiting Mayo the narrator also has the album with him and that the lonely hours he spends in his father's house (Michael goes fishing for a giant salmon, his obsession) are in part devoted to contemplating the moments captured in the photos. Thus, the fragmented structure of the narrative and its three subplot lines might all constitute a faithful representation of the act of exploring an actual photo album and momentarily immersing oneself in the miniature realities the images have arrested. Each photo evokes a different story, complete with its characters, the location, the smells and the noises; a glance at the subsequent image immediately moves the narrator away from the story he has been recalling and obliges him to begin re-constructing a new one.

Early in the novel the protagonist confesses: "I became the camera, the camera-man ... I walked into the photos, parted the canvas door of the tents ... talked to the women" (McCann 1995: 22, italics mine) and later, while looking at photos his father took in the Bronx, he adds: "They have no names when I walk to meet them, these immigrants. But I know their jobs ... " (McCann 1995: 136, italics mine). Songdogs is not a novel about observing passively, glancing indifferently at black and white snapshots of distant realities; on the contrary, McCann's book engages past events actively - the narrator's gaze scrutinizes each image, reads deep into its details and attempts to re-construct its complete context: the precise moment a photo was taken, the atmosphere, the movements, the emotions felt by the persons captured. By looking at the photographs the protagonist becomes the owner, the master of each moment, for it is he who assigns signification and converts static, still images into vivid mini-narrations full of motion and life. His gaze is creative; rather than simply witnessing past moments the narrator actively embraces them, metaphorically enters their realities, "walking into the photos", and brings them back into momentarily existence, immersing himself into surrogate experiences he never had.

On the surface, Songdogs is organized by a traditionally-handled, linear temporal frame, which limits the novel's time span by imposing a rigid division into sections corresponding to the seven days the narrator spends in Mayo. Underneath that firm super-structure, however, McCann carefully elaborates a kaleidoscopic interplay of images that fracture the smooth narrative surface and divert the linear plot along much less restrictive paths. Constantly submerging himself only to re-appear on the narrative surface once again, the protagonist appears to be literally voicing his impressions upon looking at old photos, distracted from time to time by his own reality, his father's shabby and miserable country-house. Fully aware that his visit in Mayo is brief, the narrator consciously confronts past enigmas and mysteries so that upon his imminent departure the scattered images that somehow suggest and represent his own memory might be properly ordered, as in a photo album.

\section{Reconstructing the past}

The surface plot line of McCann's novel is set in contemporary Ireland, yet the country as such is not highly contextualised, in the sense of visibly pointing towards a particular spatial or social presence. Apart from sporadic references to the Irish political past and present, such as mentioning election posters of Fine Gael and Fianna Fáil, the great famine of the $19^{\text {th }}$ century or the continuous migration of young people in search of a better life abroad ${ }^{4}$,

\footnotetext{
${ }^{4}$ Some critics have observed that, given the rapid economic developments experienced by Ireland and the consequent changing social patterns, migration as such does not constitute an indispensable experience confined to Irish reality. Christina Hunt observes: "Exile continues to be a fact of life and a staple of fiction; but Irish emigrants in books, as in reality, now show up in unlikely places, and are rarely forced to remain there against their will indefinitely" (Hunt 198: 275). Interestingly, Hunt's commentary juxtaposes the present experience of emigration, understood in terms of a personal opening-up to the world, with the more traditional vision of poverty-struck Irish men and women fleeing their hostile homeland and populating the lowest ghettos of great industrial centres.
} 
the novel does not explore history on a broad, national level that would allow it to be read as dramatising a common (Irish) experience; instead, it deals with past reconstruction on a more private, personal level.

Even though the protagonist's main reason for returning to Ireland is the renewal of his green card (he has settled in Wyoming, in the same area his parents visited in their journey across the United States), it becomes evident that the questions of his family's history, its (his) heritage and the mysterious disappearance of his Mexican mother Juanita continue to haunt his mind and constitute the underlying stratum of tension that somehow conditions Conor throughout his life. The protagonist explains that his motive for actually abandoning Mayo after his mother disappeared without leaving so much as a good-bye note was to establish his own identity, to understand who he actually was: "These days in London ... I pondered my dual heritage, the Irish in me, the Mexican ... I had wanted to announce my manhood ..." (McCann 1995: 42). Soon, however, the narrator realises that the true nature of the longing he experiences is actually to find his mother, to be again re-united with the person who used to embody closeness and parental care:

In bookshops ... I looked at guidebooks to Mexico, wondering if my mother might step out from the pages and appear to me ... In those bookshops ... I decided that I would make my trip to my mother's country, find her, make her exist for me again (McCann 1995: 42-43).

The longing remains unsatisfied until the end of the novel when the protagonist actually confesses it to his father:

\section{'You know where I was, Dad? Those first few years when I was away? You know where I was?' \\ 'Where?' \\ 'I was looking for Mam' (McCann 1995: 191).}

The narrator's search for her had proven futile - none of the places he had visited and none of the persons he had met during his journeys had been able to direct him towards his mother or so much as give him indications of her whereabouts. Juanita had disappeared without a trace, leaving the protagonist suspended in the greatest of uncertainties: that of not knowing, or not understanding, one's roots. Apparently, the only way to somehow liberate these phantasmal obsessions is to face the one held responsible for all the miseries the narrator's father ${ }^{5}$.

The re-encounter takes place in Mayo, but for Conor the homecoming implies a new recreation of all the facts and suppositions about his parents' lives he has been able to gather. The primary source of these is his photo album - as has already been observed above, the protagonist has the habit of looking through its contents and 'entering' the realities captured by the images via the constructive power of his gaze. Throughout the novel the narrator often immerses himself in the diverse temporal and spatial contexts held prisoner within the snapshots - the Madrid bombing photos from the Spanish Civil War, mining camps in the deserts of Mexico, the disastrous forest fires in Wyoming or the busy streets of working-class Bronx, for example - yet his primary interest are the photos that immobilize instances and moments from his parents' past, a past he attempts to recover.

Upon 'entering' the images the protagonist appears to engage himself in a process of double-reconstruction: on the one hand, his gaze retrieves significance from the photos in

\footnotetext{
${ }^{5}$ Throughout the novel the protagonist confesses the negative feelings he experiences towards Michael: “ ... even when I hated him ..." (McCann 1995: 173), 'Ask my bollocks,' I said. From then on, that was one of the few things I said to him" (McCann 1995: 210) or " ... and I had come home, detesting my father ..." (McCann 1995: 183). It is important to point out that although the commentaries come from different time points and even different plot lines they were all made after the publication of the first erotic album with mother's photos. Initially the protagonist was not aware of the actual implications of his father's project, yet the constant taunting he experienced at school and in town, followed by his unauthorized incursion into his father's darkroom, eventually reveal to him the true significance of the photo album: "A huge feeling of sickness rose up in me ... I remember feeling as if a big vacuum was sucking the air from me, dry-retching, a world churning in me ..." (McCann 1995: 174). Conor's reconstructions of his childhood usually depict Michael as a distant, reserved and basically uninvolved father, which might explain the protagonist's close attachment to his mother and the consequent powerful desire to find her.
} 
his album and, on the other hand, Conor recalls all the stories that beginning with early age up until manhood formed an essential part of his every-day experience: "It was only with enough tequila in my system that I could make sense of the stories my parents had told me, their endless incantation of memories" (McCann 1995: 68, italics mine) or "Long ago, when they told me their stories about Mexico, Mam and Dad, I believed they were true" (McCann 1995: 72). Understanding perfectly just how important these maternal and paternal narratives were, the narrator states:

They were my songdogs ...They tried very hard to tell me how much they had been in love with one another, how good life had been, that coyotes really did exist and sing in the universe of themselves on their wedding day (McCann 1995: 72-73) ${ }^{6}$.

The stories told by his parents constitute Conor's sense of self and his understanding of family heritage, which might explain his particular obsession with recovering the past. Born to a mixed-blood couple of nomads, young Conor cherishes all the narratives he is offered as if they could replace the ultimate incompatibility of his father and mother with a series of referents that would constitute a familiar context, a sense of tradition. The protagonist's hopes prove illusory, for eventually the family breaks up (with his mother's disappearance) and the delicate identity framework becomes shattered; consequently, the narrator leaves Mayo and embarks on his journey with the aim of visiting the places and resurrecting the moments that populate the stories he remembers.

In this respect, the encounter with Cici, a hippie and ex-friend/lover of his mother's, proves particularly illuminating as it enables the protagonist to gain access to a vital part of his parents' experiences in San Francisco and then Wyoming; above all, Cici reveals some

\footnotetext{
${ }^{6}$ The protagonist explains that, according to Navajo cosmogony, it was a pair of coyotes that summoned the world into existence through their incessant howls. By recalling the Navajo myth and later denoting the parents as "his songdogs" (which is the name used to refer to the original coyote couple) the narrator establishes a parallelism between the animal howls that create the world and the stories that create identity and personality.
}

highly intimate details about his mother's emotional condition and their brief amorous adventure. The narrator comments: “ ... she [Cici] sang to me like a wren, on and on, memories of startling lucidity, incidents pouring from her ..." (McCann 1995: 112), in a sense comparing the woman to his parents, emphasizing her own particular interest in and respect for telling stories. Although apparently the narrator's quest for information, a metaphorical recreation of the traditional mythical quest for knowledge and understanding, is successful, Cici warns Conor that memories, no matter whether pertaining to first-hand experiences or not and irrespective of their lucidity, have the inevitable quality of subjectivity, which seriously questions their status as faithful reconstructions of past events:

'You know what I think?' she said. 'I think memory is three-quarters imagination.'

I sat back.

'And the rest is pure lies' she said. (McCann 1995: 112, layout original)

Conor apparently accepts this condition of the revelations he is offered; yet his interest in Cici's narrations does not diminish. He is willing to listen for he has a way of actually cross-examining at least part of what he is being told - he has the photos. Equipped with, on the one hand, the images and, on the other hand, the narratives he has memorized Conor might attempt to re-construct a life-story full of joys and sorrows, illusions and deceptions, moments of frantic movement followed by almost interminable periods of stasis. Departing from either the visual or the verbal realm of knowledge, the protagonist of Songdogs is able to juxtapose its contents against the other medium and thus verify whether his original suppositions were correct or not $^{7}$; this process of comparative re-creation might be said to constitute the novel's main

${ }^{7}$ In this respect the protagonist resembles a detective figure who has to organize all the available evidence in order to draw proper conclusions and, consequently, solve the mystery. Interestingly, the detective figure can be, in turn, traced back to the original knowledge quest and its character, a mythical hero, whose task consisted precisely of gathering items/pieces of information and later employing them to his advantage in order to succeed in a challenge/test. 
theme. It portrays a desire to know one's roots and the extent to which this desire might become the driving force in man.

Irrespective of Conor's efforts, the central enigma of the story, his mother's disappearance, remains unsolved. Even the father himself is unable to shed light on her possible destination, although the old man does confess that he is also deeply troubled by Juanita's painful absence: 'No, no, you don't understand. I really miss her. I honestly miss her' (McCann 1995: 206). Unlike his son, however, Michael adopts a completely different attitude with regard to past events, an attitude which does not bring relief either - he chooses not to remember": 'Ah, Jaysus,' he said. 'I remember nothing at all these days' (McCann 1995: 190) or 'All I'm looking for is a bit of peace and quiet. Go away. Let me sleep' (McCann 1995: 191). It is interesting to observe how father and son are driven by exactly opposed desires: the former desires completion through knowledge while the latter seeks comfort through oblivion and whereas Conor's motivations appear easy to decipher, the old man's rejection of all that was might cause problems. One way of interpreting it requires a brief digression into the father's younger days; early in the novel the narrator comments upon Michael's understanding of photography as preserving past moments without altering them and, consequently, immortalizing the instants the lens captures: "It was something the old man often did - if a moment existed in a photograph, it was held in that particular stasis forever. It was as if by taking a photo he could, at any moment, reinhabit an older life ..." (McCann 1995: 23). Consequently, the father might be said to coincide initially with his son's idea of recreating the past through still images, which could explain, on the one hand, the great number and the underlying, highly erotic quality of the photos he took of his wife

\footnotetext{
8 A traditional, psychoanalytical reading of the character would undoubtedly comment upon negation being one of the primary defensive mechanisms our self employs and would possibly argue that the father's unrealised desire is the cause of his suffering. Although the present paper is not, strictly speaking, a psychoanalytical study, it is ready to accept the notion of negation as one possible interpretation of the father's conduct.
}

and, on the other hand, his sudden disinterest in past times after these photos, together with all the potentially re-constructible realities they contained, were destroyed. Unable to resurrect history and his memories without the artificial aid of his images, Michael abandons the notion of preserving past moments and, instead, concentrates himself around commonplace, present activities that in no way evoke the painful loss he has suffered.

Conor's homecoming dramatises the inevitable tension between past and present in yet another way; the figure of Michael is in general idealized in both sub-plot lines, in which he is represented as independent, selfsufficient, resistant and virile: “... I love him for the gigantic way he walked ... " (McCann 1995: 173). On numerous occasions the protagonist recalls his father purposefully displaying his body to be admired in public, " ... an arm cocked histrionically to show a muscle" (McCann 1995: 164), being highly authoritarian or even despotic. The old man Conor encounters in Mayo has none of these qualities; his body is dry and wrinkled, his hands tremble, he can no longer keep the house ordered. Images of the misery of old age are frequent in Songdogs: "His neck was a sack of sag and his trousers were huge on him" (McCann 1995: 15), "He dribbled egg down the front of his chin this evening at dinner" (McCann 1995: 61) or "A smell filled the room and I knew straight away why he had been trying to send me downstairs" (McCann 1995: 153). Michael's poor condition is another painful reality the protagonist has to acknowledge - preserved in Conor's memories and photos as the strong man he once was, Michael is slowly facing imminent death and there is no remedy that could possibly stop the process. The coming to terms with his father's misery might be said to constitute the other great challenge to the protagonist's integrity ${ }^{1}$ and his ability to successfully integrate both

\footnotetext{
9 Simultaneously, the narratives also depict Michael's preoccupation with old age and his initial efforts at disguising its first signs, such as loss of hair. In general, the protagonist's father appears not to be able to cope with the inevitable changes that accompany linear time. The theme will be developed more thoroughly in the following section.
} 
past and present into a significant continuum.

\section{A gaze that wants it all}

The previous sections of the paper have made reference to the concept of the gaze, understood as a particular way of looking that presupposes and mirrors the workings of desire around the figure involved in that act of looking, the voyeur. In McCann's novel the gaze does not only have the function of facilitating a recreation of the past, however; it might be argued that the concept can also be applied to analysing the figure of Michael and, in particular, his obsession with photography that ultimately caused Juanita's disappearance.

It has been stated above that Michael's interest in taking photos is directly connected with his belief in actually immortalising past moments using a camera. It has to be added that from the very moment Conor's father met his future wife in rural Mexico, an unspoken pact was established between the two: "She wasn't performing for the camera - she was performing for him. She never asked to see the prints. There wasn't an ounce of vanity in her poses" (McCann 1995: 38). Thus, from the outset Juanita allows the camera and, more importantly, the man behind it, to capture images of herself, of her body, as if she were giving it away, offering it to the stranger from remote Ireland. Also, beginning with the first photos the highly erotic character of the images predominates: "Some of the shots were hazy beneath mosquito nets, so they took on a Victorian attitude of lounge and lust ..." (McCann 1995: 59) or "He still makes a temple from her body ..." (McCann 1995: 141). There is no opposition to the ambience of the photos on the part of Juanita as long as their highly intimate content remains within the family, between the cameraman and his model; yet, towards the end of the novel Conor admits that while the family was still living together in Mayo his father collected the erotic images of Juanita (and some nude photos of other women he had taken earlier) in two consecutive editions that he first attempted to sell in Ireland (the album was banned) and then abroad, primarily in France. Although Juanita never openly opposed the idea, the way young

\footnotetext{
${ }^{10}$ The primary one being, as has been argued above, the ultimate impossibility of recovering his mother.
}

Conor remembers her afterwards and her decision to burn both the first edition of the book and the entire darkroom where the second one was stored strongly imply disagreement, frustration and rage on her part. Her final act of abandoning Mayo might also be interpreted as a direct consequence of seeing her nude photos become public.

Why did Michael take all these photos or, more importantly, why did he have them published living in a small rural community of Catholic background whose reaction - social stigmatisation - was fairly easy to predict? In order to answer both questions Michael's initial attitude towards the past must be recalled yet again; by taking photos he believed to be forever preserving the instances that constituted his experiences and the persons that populated them. Surrounded by his images, he would simply never forget. A similar explanation might be given with regards to photographing his young and attractive wife - each erotic image taken would comprise an ever-lasting testimony of her beauty, the freshness of her skin, the perfect contours of her limbs. The narrator comments: "It was as if he [Michael] believed that something that was has the power to be what is" (McCann 1995: 23, italics original). Taking nude or partially exposed photos of Juanita signified possessing her beauty forever, guarding it against change and the horror of old age; it might be concluded that the intimate images were supposed to constitute Michael's private, easily-accessible artificial memory, a surrogate for man's imperfect ability to recall.

Michael's was a gaze that possessed; unlike Conor, who through the act of looking recreated and assigned new meanings to particular signifiers, his father trapped possibly variable meanings within the stillness of Polaroid paper. The latter's gaze might be said to challenge the passage of time, to rebel against a progressive understanding of temporality, to defy the uniqueness of each given moment; the narrator thus comments:

He [Michael] wanted a memorial of some sort, en epitaph for himself, a package of light to emerge and print itself indelibly on his life, to say: I was once great, look at these great photos I took, look how perfect they are, look how I once lived, I was alive! (McCann 1995: 171, italics original). 
By defying the past in this way Michael wanted to achieve immortality, understood by him as the ever-lasting existence of an essential part of his persona ${ }^{11}$; despotic as he was, however, Conor's father believed that others, above all his wife, would actually share his particular attitude towards the past and acknowledge his photo albums as something more than just nude images. The protagonist himself acknowledges such a possibility and states: " ... maybe he truly believed that it [the album] would reinvent things, maybe he thought it was a gesture of love - that she [Juanita] could look at the pages and remember herself" (McCann 1995: 171). The protagonist himself acknowledges such a possibility and states: " ... maybe he truly believed that it [the album] would reinvent things, maybe he thought it was a gesture of love - that she [Juanita] could look at the pages and remember herself" (McCann 1995: 171). The problem is,

\footnotetext{
${ }^{11}$ Michael's attitude might be said to coincide with the ideas of the ancient Greek poet Horace, whose best known piece, entitled Exegi monumentum, portrays a great man attaining immortality through the superb quality of his verses.

I have wrought a monument more lasting than bronze

And loftier than the peaks of the regal pyramids, Which neither the gluttonous rain, nor the blustering wind

May destroy, or the innumerable

Series of years and the flight of times.

I shall not wholly die, and a good part of me

Will surmount Libitina: Always shall I, with future

Praise, arise and become new, so long as the Capitol

The Pontiff with the calm virgin scales.

I shall be said; where resounds raging Aufidus,

And where Daunus, poor in water,

Ruled his rustic peoples; to have become from insignificant

The first able to Aeolian song into Italian

Verses lead. Take exquisite pride

In these merits, Melpomene, and with the Delphic Laurel willingly crown my hair.
}

A man's achievements, most notable his artistic creations, will forever remain present within the invisible strata that constitute human knowledge. Michael appears to share such an understanding of art; his photos will glorify his life and constitute an imperishable testimony of his experiences.
Conor's mother cannot view the album in the way Michael would like her to; her idea of the past and her notion of identity must have been completely different from his, and the drama in Songdogs is provoked precisely by the incompatibility of their respective views. Although Michael's intentions might have been partially noble (if one accepts his commitment to immortalizing Juanita's beauty for her), his supposing that she would appreciate the album was infinitely mistaken; unable to sense an important discrepancy with regards to the notions of, on the one hand, intimacy and, on the other hand, the relation between present and past, Michael commits a sacrilege that his wife will neither comprehend nor forget. The most intimate of offerings she could ever make, the unconditional surrender of her body to the cold lens of the camera, a surrogate for Michael's own eye, becomes perverted and publicly exposed; the photos, instead of communicating sensual closeness and private devotion, satisfy vulgar desires of Mayo's inhabitants, anonymous strangers who in no way partake of the original, intense significance of the images.

It is also interesting to emphasize again the highly erotic character of the photos - they are in fact the only allusions to the sexual in the novel. None of the three plot lines includes any mention of sexual relations, with the exception of a fragment included in Cici's narrative about her brief (and not explicit in the least) adventure with Juanita while the three of them were living in a watch tower in Wyoming. In Songdogs sensuality understood in terms of physical desire or contact is somehow displaced - not by the characters, but by the narration itself; all that denotes sexuality within the text is removed from its usual set of references and re-distributed, so that it functions exclusively within and through the photos. Michael's desire for Juanita, and other women as well ${ }^{12}$, is translated entirely into

12 Early in the novel the narrator points to his father's apparent lack of interest in young girls during adolescence. Still an amateur photographer Michael already viewed the feminine as a theme for his images, rather than the object of an emerging sexual desire: "Sometimes the girls would try to get him to come in and dance, but it didn't interest him, dancing, unless he could take a picture of it" (McCann 1995: 11). 
the realm of the visual - in his adolescence, instead of courting women, Michael takes photos of them. During the Spanish Civil War episode he accompanies the Fascist army and portrays with morbid detail, but also perfect reserve, how the soldiers satisfied their carnal desires with prostitutes. Although explicitly present, the sexual is always one step removed from Michael; it is always a theme, an element that is observed, but never actually embraced. It could be stated that his possible desire is satisfied through looking at the desire of others - if such a reading is accepted then Michael is the prototypical voyeur, one whose satisfaction depends on a guarantee of distance between the desired object and himself, rather than proximity and physical contact.

One of the most significant difficulties that emerge while a nation's literature is being discussed, any nation's literature, is whether the body of literary works in question reflects the national experience, the "-ness", as in Irishness in the present case, of a given culture. Although a great number of themes and motifs present in fiction are considered universal, and thus not restricted to any given national or temporal frame, there is nevertheless a strong pressure on writers, especially the young ones, to somehow embrace realities proper to their own immediate surroundings and echo a set of conditions that is not easily found outside their social group, their era, their nation.

This problem is particularly visible in the case of Irish writing and, even more importantly, in Irish prose. A number of critics have observed the slightly undeveloped (in the sense of not innovative, traditionalist) character of Irish narrative writing in the late $19^{\text {th }}$ and early $20^{\text {th }}$ century, with the obvious exceptions of Joyce and later Beckett. Christina Hunt Mahony observes:

\section{... Irish men and women who have chosen to write not poetry or plays, but to use prose as their medium of artistic expression, have worked in a tradition that has been considered less developed and certainly one that has been less touted (Mahony 1998: 18).}

The fundamental reason given to somehow explain this awkward condition of Irish prose is the country's history, the centuries-long English occupation, which inevitably affected all the domains of Irish life, including its artistic and literary production. Being a colonial entity meant that Ireland was forced to accept elements of English culture as its models and continuously juxtapose its own achievements against foreign patterns that often had very little in common with Irish reality; for a long time 'Irish' meant inferior only because it was directly opposed to 'English', the label that embodied the dominant culture. Also, as Mahony points out, the Irish literary tradition has been more likely to embrace poetry or drama as its preferred means of expression, mostly due to their primal dependence on the highly expressive character of particular words, on their aesthetic charge and on the rhythmic quality inherent in the two modes of writing.

Prose writing does not depend so much on such a careful selection of vocabulary and novel writing least of all; while in a short story the principle of economy of language introduced into literary study by E. A. Poe and later fully acknowledged by other great shortstory writers and scholars alike, such as Julio Cortázar or José María Pozuelo, preserves its validity until the present day, a novelist, working with much more extensive material, may be permitted a more laissez-faire attitude towards the language employed - its impact depends rather on an elaborated structure and a gradual, and complete, development of its inner tensions. The latter is certainly true of McCann's Songdogs; as has been pointed out in the previous section, the novel is static and apparently predictable in terms of narrative events. Action or movement, understood literally as spatial displacement, are scarce, which does not, on the other hand, imply monotony or simplicity in the work's construction. In fact, it is precisely the structure of the novel that might be regarded as McCann's greatest achievement - the writer manages to mingle the three plot lines and continuously divert the sub-narratives so that the informative gaps that punctured the texture of the three stories, their initial incompleteness, can eventually be filled with meanings retrieved from the incursions into the numerous mini-narrations embedded in the larger plot lines. Reading McCann's novel obliges the reader to engage in a difficult process of active re-enactment, not only of the novel's reality (realities), but also of its very structure; accustomed to linear time and the logical cause-effect chain, McCann's readers 
find themselves in an apparently chaotic narrative framework that almost frivolously rejects both chronology and causality in favour of a more personal, experimental, mode of constructing a literary reality.

Thus, from this perspective, reading Songdogs implies a labour of active reconstruction; interestingly, the same task is also the principal theme of the novel, which in a way places both the reader and the protagonist in a similar position. McCann's work constitutes an account of Conor's efforts aimed at disentangling his family history and structuring it properly so that it can become a revelatory experience, a personal epiphany; wandering the world without a clearly defined destination, the protagonist revives the stories his parents left him and, simultaneously, constructs his own identity. Songdogs dramatises the experience of an interior vacuum, an internal hollowness that does not allow an individual to know its precedence and, consequently, its ultimate destiny. In this respect, past and future are not two clearly defined, separate temporal frames that could function independently from one another, which Michael is desperately and fruitlessly trying to demonstrate - they constitute two extremes of a continuum and their successful reconciliation, the coming to terms with one's past in order to embrace a better future, can only be achieved in present time, an elusive meeting point where tradition collides with prospect. In his book that investigates Irish culture (and writing in particular), Robert Welch makes the following comment: "Irish culture is preoccupied by continuity" (Welch 1993: 5); although Welch's argument is centred around the concepts of activity, understood by the scholar as change and innovation, as opposed to inertia, an apparently un-productive state of exploiting the already existing models and patterns, the critic readily recognises the importance of continuity with regards to the temporal. A present meditation on one's possible projects is impossible without taking into account one's past experiences and their implications; advances and progress, efforts aimed at constructing a better, more efficient or more complete tomorrow are bound to fail if no heed is paid to that which made the advances possible in the first place - the past.
Apart from portraying the process of past reconstruction, which would ultimately affirm the novel as representative of an Irish experience (as pointed out in the initial paragraphs of the paper), Songdogs engages yet another issue involved in the re-enactment of history - the authenticity of the sources. As has been observed, Conor has at his disposal two sets of evidence: the verbal, constituted by the stories told to him by his parents and later Cici, and the visual, the collection of photographs taken by both his father and himself. In the course of a comparative exploration of the two registers he is able to construct an apparently complete and logical recreation of his parents' life; the term "apparently" must be emphasized because although Conor is satisfied with his labour almost all the informative gaps have been filled with plausible content - there is no possibility of objectively proving the fidelity of the story he possesses. Are memories, the memories of others' memories and still images enough to reconstruct a life? Is it sufficient to order the images and align a number of mini-narratives in order to recover the original, master plot? Although Conor appears to second an affirmative answer, Cici's warning, "memory is three quarters imagination and the rest is pure lies", looms above his efforts, challenging their authenticity.

Although Songdogs does not include any direct reference to New Historicist ideas, Cici's commentary cited above does recall the ideas of Michel Foucault and other scholars who, in general, opposed $18^{\text {th }}$ and $19^{\text {th }}$-century historiography and proposed a more subjective, less essentialist understanding of history. Instead of considering it ultimately true and stable, the New Historicists argued the existence of multiple histories, personal narratives that disclosed a subjective reading of past events. In his investigation of Joseph Conrad's Heart of Darkness, Brook Thomas explains: “ ... no history can possibly relate the past as it really was because our histories will always be influenced by our present perspective" (Thomas 1989: 239). One's ideology, experiences, social circumstance and the language one employs are all factors that influence one's perception of the world, and any subsequent re-construction of that world will be highly affected by these factors. As has been pointed out, however, Conor pays little 
heed to Cici's words - he wants to believe the stories because through them he constructs his own identity; without a credible history he would forever remain suspended in a personal void of ignorance. Conscious of the possible fallacies inherent in trusting memories, especially those of others, he is willing to sacrifice fidelity in exchange for an identity. McCann's protagonist might be said to embody one of mankind's most profound dramas - its ultimate dislocation, a removal from any social context accompanied by a desperate longing to belong, to attach oneself. Fortunate enough to produce a credible history for himself, Conor encounters inner peace; particular emphasis should be placed on the word 'produce', however, as it dramatises the artificial character of history, and thus identity, which no longer constitute intrinsic qualities of the human condition. Instead of being taken for granted, they must be forged out of stories, memories or images and the very process of elaborating one's history, and also identity, comprises one of the greatest tests modern man undergoes.

The act of reading fiction presupposes a pact between the reader and the narrator, or the text ${ }^{13}$; although nobody doubts the essentially fictional, not real, character of both the protagonists and the events described, disbelief is temporarily suspended in order to take pleasure from reading. In Songdogs, the said pact is duplicated; in the first place, the reader agrees to accept the existence of a fictional persona named Conor who has a fictional father named Michael and that they share a fictional family history around which a series of fictional events is constructed. In the second place, the very nature of these events and their supposed relations are seriously doubted from within the narrative. Once the initial pact has been made, which in technical terms implies a temporal coming-into-being of a fictional reality that constitutes the novel's setting and

\footnotetext{
${ }^{13}$ The idea of a pact between the reader of fiction and the text boasts a long tradition in Western literary tradition; poignantly expressed by Coleridge as "a willing suspension of disbelief", more recently it has attracted the attention of the theory of fiction. In particular, the pragmatic approach to fictionality appears to generally employ the notion of the pact in analysing the performative force of fictional statements with regards to the reader.
}

its three plot lines, the truthfulness and objectivity of these very elements become questioned and, consequently, the second pact is necessary: the reader is asked to give credence to Conor's efforts at re-creating his parents' past and the story he eventually reconstructs. In this respect, the novel exposes from within the primary condition of any work of fiction - the ephemeral quality of the "truth" it supposedly contains. Whether a work of fiction, be it a novel, a short story or a film, is based on authentic testimonies of first-hand witnesses or highly detailed personal narratives, its fictional character remains constant; no story is more true than another one. Any imagined narrative is as fictional as a heavily documented historical novel - none of them ever actually happened. While the former might be pretty straightforward about its own fictionality, the latter simply constitutes a version, an artistic recreation of particular events based on persons or facts taken from real life. On the other hand, the nature of the pact between a reader and a text suspends these conditions and consequently allows the readers to immerse themselves in the reality proposed by a work of fiction. In Songdogs, this immersion is twofold: in the first place, the text offers the surface story with its three plot lines and its two principal characters, witnessing their painful encounter and the slow reconciliation; in the second place, the act of reading organises the three plots into a logical continuum and allows an exploration of different fictional realities not included in the surface plot line. Moreover, the character of Juanita, the absent persona reconstructed exclusively on the basis of stories, images and memories, can only be accessed via the sub plot lines.

Songdogs is a novel about looking, observing and re-constructing through scattered snapshots of anonymous places, private moments, and people's faces. It constitutes a meditation on the modes in which history, be it personal or more universal, can be enacted and made one's own; simultaneously, it clearly separates the notion of history from the category of objectivity, considering them both ultimately opposed there is no such thing as an essentially true, global history. Instead, the past constitutes an amalgam of impressions, voices or visions that might coincide or not in their treatment of 
particular events or persons, producing a kaleidoscopic image of what once was considered a monolith. Memory, McCann appears to be saying, is a useful tool on a personal level - it might serve the purpose of satisfactorily reconstructing history. For it to be successful, however, one condition has to be met: the version produced is not to be contrasted against any other version, in which case discrepancies are bound to appear. History is thus a fundamentally private concept and any attempt at sharing it presupposes sacrifice - compromise with regards to past events often implies edition and re-elaboration of a new version, more or less different from its originals. In the end, plurality and universality with regards to experience appear to be the two major tensions whose complex interplay and development comprise the mode of McCann's Songdogs.

\section{Works Cited}

Campbell, Joseph. 1993. The Hero With a Thousand Faces. London: Fontana Press.

Cortázar, Julio. 1992. "Del cuento y sus alrededores." Obra crítica/2. Madrid: Alfaguara. 399-407.

Freud, Sigmund. 1988. "La Interpretación de los Sueños" Freud: Obras Completas Vol. 3. Barcelona: Ediciones Orbis, S. A.

Hand, Derek. The future of contemporary Irish fiction. Irish Writers' Centre. http://www.writerscentre.ie/anthology/dhand.html

Horace. Exegi monumentum. http://plaza.ufl.edu/babax/exegi.html (translated Babak T. Lotfinia, 2001)

Lacan, Jacques. 1998. "Anamorphosis." The Four Fundamental Concepts of Psychoanalysis. London, New York: W. W. Norton \& Company. 79-90.

Losada, Friend María. 2003. "La identidad irlandesa a través de sus fantasmas literarios" Nuevas perspectivas críticas en la literatura irlandesa. Eds. Jaime de Pablos, M ${ }^{\mathrm{a}}$ Elena. Margarita Estévez Saá. Almería: Universidad de Almería. Servicio de Publicaciones. 57-68.

Mahony, Cristina Hunt. 1998. Contemporary Irish Literature: Transforming Tradition. London: Macmillan.

McCann, Colum. 1995. Songdogs. London: Phoenix.

Poe, Edgar Allan. 1970. "The Philosophy of Composition.” Tales, Poems and Essays Ed. G.F. Maine, London, Glasgow: Collins. 503-513.

Pozuelo Yvancos, José María. 1999. "Escritores y teóricos: la estabilidad del género cuento." Asedios ó conto. Ed. Becerra Suárez, Carmen. Vigo: Universidad de Vigo. Servicio de Publicaciones. 449-472.

Thomas, Brook. 1989. "Preserving and Keeping Order by Killing Time in Heart of Darkness." A Case Study in Contemporary Criticism. Ed. Ross C. Murfin. New York: Bedford. 237-258.

Vance, Norman. 1990. Irish Literature: A Social History. Tradition, Identity and Difference. Oxford, Cambridge, MA: Basil Blackwell.

Welch, Robert. 1993. Changing States: Transformations in Modern Irish Writing. London, New York: Routledge. 